\title{
ЛИТЕРАТУРОВЕДЕНИЕ
}

UDC 821.411.21

\section{The Image of Authority in Basma Abd al-Aziz's Dystopian Novel The Queue}

\author{
A. A. Mokrushina \\ St. Petersburg State University, \\ 7-9, Universitetskaya nab., St. Petersburg, 199034, Russian Federation
}

For citation: Mokrushina A. A. The Image of Authority in Basma Abd al-Aziz's Dystopian Novel The Queue. Vestnik of Saint Petersburg University. Asian and African Studies, 2021, vol. 13, issue 2, pp. 132 136. https://doi.org/10.21638/spbu13.2021.201

\begin{abstract}
The article presents an overview of the new dystopia genre in Arabic literature as well as the main reasons and prerequisites for its appearance. The interest of Arab authors in the newly discovered genre of the dystopian novel has grown markedly, which is primarily due to serious political, economic and social changes affecting the region. The situation in some Arab countries offers many avenues in which society can develop, and literature was the first to respond to this. Egypt has become one of the centers of global change that has affected the Middle East. Young Egyptian intellectuals tend to soberly assess the situation that has developed since the Arab Spring and writers have offered their own vision of the situation in the country. As an example of a modern dystopia, the novel The Queue by Basma Abd al-Aziz was chosen. The Queue does not have a traditional dystopian oppositional character. However, of the significant images of the novel to which the writer draws attention is the image of authority, which is impersonal and inaccessible to the common people. There is no mention of the name of the country where the events of The Queue unfold, but the reader easily recognizes Egypt. In the study a comprehensive approach was used, as well as cultural and sociological methods of analysis and interviews.
\end{abstract}

Keywords: modern Arabic literature, novel, dystopia, authority, Egypt.

In recent years, the interest of Arab authors in the newly discovered genre of the dystopian novel has grown markedly, which is primarily due to serious political, economic and social changes affecting the region. Attempts to find answers to important social issues are reflected in a number of critically acclaimed dystopian novels, many have been

(C) St. Petersburg State University, 2021 
translated into foreign languages. The situation in some Arab countries offers various avenues in which the society can develop, and literature was the first to respond to this.

Of late, Egypt has become one of the centers of global change that has affected the Middle East. This, as well as the literary experience of several generations of prominent Egyptian writers, well-known both domestically and internationally, are the reason why the names of modern Egyptian writers are often mentioned in connection with a new genre for Arabic literature - the dystopian novel. It is also significant that most writers who have established themselves in this genre are in their thirties. Young Egyptian intellectuals tend to soberly assess the situation that has developed since the Arab Spring. Although most Egyptians were initially euphoric about the events, they then became disappointed young writers who have offered their own vision of the situation in the country [1, p. 68]. In his Science Fiction and the Arab Spring: the critical dystopia in contemporary Egyptian fiction, Sinead Murphy argues that "at the heart of each of these narrowly-fictionalized parallel worlds is the Arab Spring, the causes and conditions of which fundamentally inform the structure and trajectory of each dystopian account. At the same time, the differences between each text indicate significant variation in lived experiences of the uprisings, and the diverse perspectives on its outcomes across the region" [2].

The emergence after the events of 2011 of the Egyptian Society for Science Fiction should serve as a confirmation of this statement. The society sees as its goal not only the analysis of existing works, but also their popularization (including abroad), supporting authors, establishing contacts with foreign colleagues and specialists involved in the study of the new genre.

Despite the fact that the dystopian genre has appeared in the repertoire of Arab writers relatively recently, some works have been praised by critics and awarded prestigious literary prizes. The dystopian novel by the young Egyptian writer Basma Abd al-Aziz The Queue is one such example [3].

Born in Cairo in 1976, Basma Abd al-Aziz received a medical degree and is currently successfully combining writing with practicing medicine. Like most of her fellow writers, Basma Abd al-Aziz addressed the topic of the formation of a new society that developed after the revolution. The Queue was published at the end of 2012, and in 2016 it came out in English translation [4].

Thanks to the help of the Egyptian Society for Science Fiction, the author of the current article was able to contact Basma Abd al-Aziz and conduct a short interview ${ }^{1}$ to understand how the author views some of the issues raised in the novel. It is interesting that Basma Abd al-Aziz herself does not consider her novel a dystopia in the usual sense, preferring not to relate it to a specific genre. Despite the author's perception, the novel meets major parameters of the genre (a critical focus on social problems; an attempt forecast events - often through the prism of absurdity; a clear distinction between ordinary people and the authorities, etc.).

Authority is one of the key images in the novel, combining dictatorship and total control over the population. The Gate, depersonalized, deprived of everything human, is the arbiter of the fate of an entire nation in the novel. It is significant that the Gate is always inactive. It is locked tight all the time, but this is precisely its strength. With the Gate, does

\footnotetext{
${ }^{1}$ Interview with Basma Abd al-Aziz. 2019.
} 
Basma Abd al-Aziz draw an analogy with the thirty years of President Mubarak's reign, to which opponents have repeatedly pointed out the need for additional reforms?

The image of the Gate, as an unshakable monumental government, which, without hesitation, is able to sacrifice the lives of its citizens, is evident throughout the story.

The main events of the novel unfold in a queue of city residents waiting for the Gate to receive them. The queue brought together representatives of different ages, professions, and social strata. They all need to obtain permission for something; therefore, they cannot leave the queue, continuing to live in it for several hours, days, and weeks. Every day the line gets longer, but the Gate does not open.

The Queue does not have a traditional dystopian oppositional character who suddenly realizes that there is an injustice, cruelty, or any other "incorrectness" in the existing world order. If there is one, doctor Tariq can fulfill the role judging by his function in the novel. Tormented by his conscience, he constantly asks himself the question of the possibility of violating the ban of the Gate to save a person's life. Basma Abd al-Aziz emphasizes the importance of Tariq's emotional struggle between being law-abiding and moral.

On the other hand, the thirty-eight-year-old Yahya, who received a serious bullet wound during the uprising, can be considered the main character of the novel as his story becomes central to the overall narrative.

Each chapter of the novel begins with a short medical certificate from which the reader learns about Yahya's health status. Each certificate is followed by a description of how Tariq finds out the information about the health of his patient.

Together with doctor Tariq, we read medical reports about Yahya's condition, and through these documents, form the image of authority behind the Gate. The narrative does not allow us to speak confidently about the nature of this authority, but the author draws its image - the power that is capable of changing the lives of a large number of people ${ }^{2}$.

The unsuccessful rebellion against the power of the Gate is referred to as the Disgraceful Events. Tariq, who did not take part in the protests, nevertheless, is well acquainted with the results. The power of the Gate is unshakable, and any attempts to shake it are doomed to failure. Through this image, Basma Abd al-Aziz draws an analogy with the authorities in modern Egypt, when the new government that replaced Hosni Mubarak's regime was not at all inclined to carry out any reforms aimed at improving the lives of ordinary people.

After some time, city residents begin to receive summons from the authorities. As a result, people stand in line waiting for various inquiries and permissions. Among them is Yahya, who is seeking permission to conduct operations to extract a bullet. The line moves only due to the fact that some petitioners, desperate, leave it. People share their stories and a journalist who happened to be nearby interviews them.

The Gate does not open, but the semblance of activity does not stop either - people hear constant appeals from the authorities. The bureaucratic machine continues to work, despite the fact that all other areas of life gradually fade away as people standing in line cannot conduct their everyday business: since the Disgraceful Events, the Gate has remained locked; it has not opened or accepted citizens, but it has not stopped issuing

${ }^{2}$ From the back cover of the Arabic edition of The Queue. 
orders [5, p. 43]. An empty sheet with the inscription "Decision of the Gate" that Yahya receives is a symbol of the inaction of the government or the meaninglessness of its actions.

Despite this, the residents of the city patiently follow the new rules; no one is ready to oppose the authorities again. And yet another meaningless instruction emanating from the Gate orders the erection of a wall around the people standing in line, supposedly for their safety.

The image of an autocratic power acting exclusively to the detriment of its people is embodied not in a specific character, but in the impersonal Gate, which, as we will learn later, always existed, but gradually changed and acquired a new form. At first, people did not know what the huge frightening building with the inscription Northern Gate was, but they immediately understood its importance for their lives [5, p. 41].

In the epilogue of the novel, the characters suddenly find out that everything around them was just a masterfully designed prank. Hidden everywhere, the cameras filmed what was happening, and for reliability, none of the participants had been let into the "game." Yahya also finds out that his wound is, in fact, a lie, and there is no need for emergency surgery.

If we talk about analogies with the events of the Arab Spring, then the hidden cameras primarily suggest some news channels such as Al-Jazeera, whose role in deliberately escalating the situation during the unrest in Egypt has been repeatedly discussed.

Thus, Basma Abd al-Aziz depicts, perhaps, the most ambitious example of gaslighting the population of an entire city. But does this not happen all the time, thanks to a deliberate policy of the authorities through the media? The author herself, in a private interview, agrees with this and emphasizes that her goal was to demonstrate that the authorities resort to a conscious distortion of the truth or outright lies.

It is interesting that the author diversifies her narrative in literary Arabic with unusual stylistic devices. The characters' direct speech is expressed exclusively in the vernacular dialect. This is why while there is no mention of the name of the country in which the events of The Queue unfold, the reader easily recognizes Egypt ${ }^{3}$.

\section{References}

1. Mokrushina A. Reality and fiction in Mohammad Rabie's novel, Otared. Vestnik of Saint Petersburg University. Asian and African Studies, 2018, vol. 1, pp. 68-74.

2. Murphy S. Science Fiction and The Arab Spring: The Critical Dystopia in Contemporary Egyptian Fiction. Available at: http://strangehorizons.com/non-fiction/science-fiction-and-the-arab-spring-thecritical-dystopia-in-contemporary-egyptian-fiction/ (accessed: 20.03.2019).

3. Hisham 'Aslan. Basma Abd al-Aziz's Dystopia in the list of Foreign Policy. Available at: https://www. alaraby.co.uk/diffah/herenow/2016/12/25/طابور -بسمة_عبد_العزيز-ديستوبيا_آنية_ (accessed: 10.04.2019) (In Arabic)

4. Mu'taz Hasanayn M. The Queue... About endless waiting and nothing. Available at: http://www. noonpost.com/content/18988 (accessed: 08.04.2019). (In Arabic)

5. Basma 'Abd al-Aziz. The Queue. Cairo, Publ. Dar al-tanwir, 2013. 252 p. (In Arabic)

Received: January 24, 2021

Accepted: March 26, 2021

Author's information:

Amalia A.Mokrushina — PhD in Philology; kodzik@inbox.ru

3 The author would like to thank Basma Abd al-Aziz, the writer of novel The Queue, for the interview. The author also thanks colleagues from the Egyptian Society for Science Fiction for their kind help. 


\title{
Образ власти в романе-антиутопии Басмы Абд ал-Азиз «Очередь»
}

\author{
A. А. Мокрушина \\ Санкт-Петербургский государственный университет, \\ Российская Федерация, 199034, Санкт-Петербург, Университетская наб., 7-9
}

Для цитирования: Mokrushina A. A. The Image of Authority in Basma Abd al-Aziz's Dystopian Novel The Quеue // Вестник Санкт-Петербургского университета. Востоковедение и африканистика. 2021. Т. 13. Вып. 2. С. 132-136. https://doi.org/10.21638/spbu13.2021.201

Рассматривается новый для арабской литературы жанр антиутопии. За последние годы интерес арабских писателей к этому жанру заметно вырос, что в первую очередь связано с серьезными политическими, экономическими и социальными изменениями, затронувшими регион. Сложившаяся в некоторых арабских странах ситуация предполагает множество вариантов развития общества, и литература первой откликнулась на эти события. Египет стал одним из центров глобальных изменений, затронувших Ближний Восток в последние годы. Молодежь из числа египетской интеллигенции наиболее трезво оценивает ситуацию, сложившуюся после событий «арабской весны». В то время как большая часть населения первое время пребывала в эйфории, затем сменившейся разочарованием, молодые литераторы предлагают собственное видение положения в стране. В качестве примера современной антиутопии был выбран роман молодой египетской писательницы Басмы Абд ал-Азиз «Очередь». Одним из ключевых образов в романе выступает власть, соединившая в себе диктатуру и тотальный контроль над населением. Врата, обезличенные, лишенные всего человеческого, оказываются в романе вершителями судеб целого народа. Показательно то, что Врата находятся в постоянном бездействии, они все время крепко заперты, но именно в этом заключается их сила. Страна, в которой разворачиваются события романа, не названа, но читатель легко догадывается, что речь идет о Египте, встречая фразы на египетском диалекте. В исследовании использовался комплексный подход, а также культурологические, социологические методы анализа и интервью.

Ключевые слова: современная арабская литература, роман, антиутопия, власть, Египет.

Статья поступила в редакцию 24 января 2021 г., рекомендована к печати 26 марта 2021 г.

Контактная информация:

Мокрушина Амалия Анатольевна - канд. филол. наук; kodzik@inbox.ru 